\title{
Uganda's Growth Determinants: A Test of the Relevance of the Neoclassical Growth Theory
}

\section{Peter Ivans Rumanzi ${ }^{1}$, Dickson Turyareeba ${ }^{2,3}$, Will Kaberuka ${ }^{2}$, Robert Ndyanabo Mbabazize ${ }^{1}$, Peter Ainomugisha ${ }^{4}$}

\author{
${ }^{1}$ Bank of Uganda, Kampala, Uganda \\ ${ }^{2}$ Makerere University Business School, Kampala, Uganda \\ ${ }^{3}$ King Ceasor University, Kampala, Uganda \\ ${ }^{4}$ Ministry of Finance, Planning and Economic Development, Kampala, Uganda \\ Email: pirumanzi@gmail.com, dicksonturyareeba@gmail.com,wkaberuka@mubs.ac.ug, mbabazize@gmail.com, \\ ainopeter@yahoo.com
}

How to cite this paper: Rumanzi, R. I., Turyareeba, D., Kaberuka, W., Mbabazize, R. N., \& Ainomugisha, P. (2021). Uganda's Growth Determinants: A Test of the Relevance of the Neoclassical Growth Theory. Modern Economy, 12, 107-139. https://doi.org/10.4236/me.2021.121006

Received: December 10, 2020

Accepted: January 26, 2021

Published: January 29, 2021

Copyright $\odot 2021$ by author(s) and Scientific Research Publishing Inc. This work is licensed under the Creative Commons Attribution International License (CC BY 4.0).

http://creativecommons.org/licenses/by/4.0/

\begin{abstract}
The purpose of this study is to investigate whether Uganda's economic growth determinants can fully be analyzed within the framework of the neoclassical growth theory. The study uses quarterly data for the period 2007-2018. The underlying empirical models are estimated using IV-GMM in the specific-to-general modeling approach. Estimates show that unlike the factor of capital stock per worker, human capital per worker persists to be a significant factor that influences Uganda's economic growth even when additional variables motivated by the endogenous growth theory are included in the empirical model. The factor of population growth remains theoretically plausible but reduces its strength of influence with the additional explanatory variables. The estimates suggest that the neoclassical growth model has the ability but does not fully explain growth variations in Uganda which manifests the theory's fractional relevance. Estimates further show that other factors such as low lending interest rates, attraction of FDI and expansion of domestic credit are important enhancers for Uganda's economic growth. Results do not support the notion of conditional convergence commonly cited in growth literature. Our point of departure from existing literature on Uganda's growth determinants is the inclusion of productivity factors motivated by the endogenous growth proponents in the empirical model as control variables.
\end{abstract}

\section{Keywords}

Neoclassical Growth Theory, Endogenous Growth Theory, Growth

Determinants, IV-GMM, Uganda 


\section{Introduction}

Economic growth and its determinants have been at the center of discussion in both theoretical and empirical growth literature. The main disquieting question of crucial interest has been: why are some countries in the world poor and others rich? Economic growth has been cited as the most powerful instrument for reducing poverty and improving the quality of life in developing countries (Phillips \& Cutler, 1998). In support of this belief for instance, Islam (2010) notes that if a country attains a sufficiently high rate of growth, it will take care of its poverty challenges automatically. There is also a general belief by macroeconomists that growth in income is a leading macroeconomic objective a given country. As a matter of policy, many developing as well as emerging economies, Uganda not exclusive, are considering economic growth rate together with low inflation as one of the most fundamental policy objectives (PWC, 2017). Given the central role of economic growth therefore, it is important to investigate factors that may stimulate it. Moreover, Nkurunziza \& Bates (2004) note that economic growth rates in developing countries are still not high enough to make a real dent in the pervasive poverty and enable these countries to catch up with other developed nations. This study therefore intends to investigate Uganda's growth determinants for the period 1990-2018.

In the existing empirical growth literature, the growth accounting framework has been dominantly used to understand the sources of economic growth and to answer the question why do some countries continue to grow faster than others? (for example, Solow, 1956; Kormendi \& Meguire, 1985; Barro, 1991; Barro \& Sala-i-Martin, 2003; McQuinn \& Whelan, 2007 among others). Since the introduction of the growth accounting, the neoclassical growth model introduced by Solow (1956) has frequently remained the benchmark framework in studying sources of economic growth of countries (Aghion \& Howitt, 1992). The neoclassical growth model it is based on a neoclassical production function which considers factor inputs and technical change (also called the residual) as the only determinants of growth in output. The fundamental result of the neoclassical growth model is that it is not possible to sustain long-term growth without technological progress due to the principle of diminishing marginal productivity. However, since the introduction of the neoclassical growth production function, a wide range of factors have been identified in the empirical growth literature to affect changes in output. In this study, we first test the significance of the neoclassical model in explaining growth variations in Uganda. We then extend on the neoclassical paradigm to include growth factors motivated by the endogenous growth theory which fundamentally comprise of productivity factors and public policies.

Though there is a plethora of authors in growth literature who have studied growth determinants of countries either as specific countries or as a panel of countries, there are limited number of studies that have used a combination of growth theories to study Uganda. In addition, the existing studies on Uganda 
have included only a few variables in the growth function, which may undermine the integrity of the estimates arising from exclusion effects. We also find some methodological concerns emanating from the fact that many of the existing studies on Uganda's growth determinants, with exception of Obwona (2002), have not taken into account of endogeneity bias which is inherent in growth models. While benchmarking the neoclassical growth paradigm, this study attempts to fill the gaps by incorporating the productivity factors in the empirical growth model in the attempt to identify growth determinants for Uganda and employing time series analytical methods that account for endogeneity to estimate the empirical growth model.

\subsection{Problem Statement}

Despite the existence of substantial literature on sources of economic growth of countries, there are limited studies on Uganda which have considered multiple growth theories to build the empirical model by including a variety of growth determinants. In some studies, authors have adopted the exploratory research design to study Uganda's growth determinants. In many of the studies on Uganda, the inherent challenge of endogeneity bias in growth models is not addressed, yet, many of these studies have not accounted for the role of productivity factors on Uganda's growth process. This study benchmarks the neoclassical growth model developed by Solow (1956) and builds on it to include the growth factors from the endogenous growth theory and uses the estimation methods that account for endogeneity bias in order to further explore the determinants of economic for Uganda.

\subsection{Purpose of the Study}

The study sought to examine the relevance of the neoclassical growth theory in explaining growth variations in Uganda.

\subsection{Objectives of the Study}

The study was launched to achieve two key specific objectives, namely:

1) To investigate the effect of physical capital, human capital and population growth on economic growth in Uganda while controlling for the effects of productivity variables.

2) To investigate the notion of conditional convergence in Uganda's growth function.

\subsection{Study Hypotheses}

The study tests the individual effect as well as the joint effect of the key growth factors engrained in the neoclassical growth model. In addition, the study tests the prediction of conditional convergence by the neoclassical growth theory. Thus the study tests the following hypotheses:

Hypothesis 1, $\mathrm{H}_{01}$ : Physical capital, human capital and population growth have no effect on economic growth in Uganda individually and jointly. 
Hypothesis 2, $\mathrm{H}_{02}$ : The neoclassical growth prediction of conditional convergence does not apply to Uganda's growth function.

\subsection{Scope of the Study}

The study is conducted focusing on Uganda's economy covering the period from 2007 to 2018. The choice of the variables in the development of the empirical model is guided by two key growth theories: the exogenous growth theory and the endogenous growth theory. The specification and estimation of the empirical model upholds the underlying assumptions of the chosen growth framework.

\subsection{Theoretical Frame Work}

This study is guided by two fundamental growth theories: the exogenous and the endogenous growth theories. These growth theories, together with empirical studies, guide in identifying the critical growth factors to include in the various models being estimated.

The exogenous growth theory, which is hinged on the CRS assumption and conditional convergence, predicts that economic growth is a function of factor accumulation such as accumulation of physical capital and Labour and Technological Progress or Total Factor productivity (Solow, 1956). Extending the thoughts of Mankiw, Romer \& Weil (1992) identified additional input; human capital as a key predictor of economic growth.

The endogenous growth theory was advanced by Romer $(1986,1990)$ and Lucas Jr. (1988, 2000). The endogenous growth model developed by Romer (1986) and Lucas Jr. (1988) argue that permanent increase in growth rate depends on the assumption of increasing return to capital. Barro \& Lee (1993) support endogenous growth model by Romer (1990) that high light the role of foreign direct investment in the growth process. The Lucas-Romer growth theory challenged the neoclassical model by emphasizing the role of endogenous factors which focus on the potential factors which can influence economic growth through technology. These factors include extra Investment in human capital stock, R\&D, ICT and technological adoption activities) as the main engines of economic growth.

\subsection{Conceptual Framework}

Given the theoretical framework as well as empirical evidence from previous research studies, the following conceptual framework is developed to further guide this study (Figure 1).

\section{Review of Related Literature}

\subsection{Review of Theoretical Literature}

\subsubsection{The Concept of Economic Growth}

The economic growth of a country, according Saymeh \& Orabi (2013) is taken 


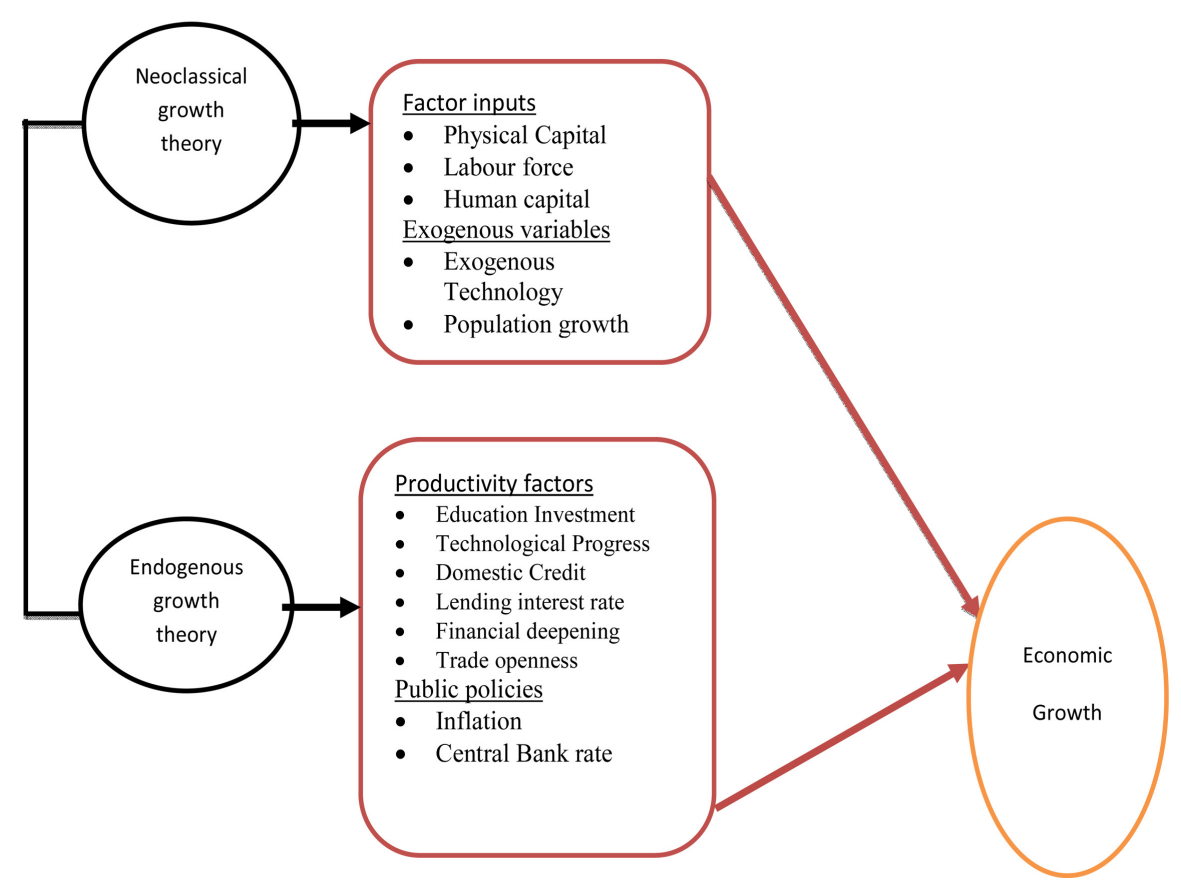

Figure 1. A conceptual framework for determinants of economic growth. Source: Adopted from Themba \& Odhiambo (2018) and modified by the authors.

to be the increase in its production of goods and services from one accounting period to another. It reflects the ability of a country or region to provide for the economic needs of the population (Nurina \& Semuel, 2015). Anidiobu et al. (2018) affirms that economic growth is the increase of real GDP or GDP per capita, an increase of national product that is measured in constant prices. Most frequently in economics and other disciples, economic growth is measured by the rate of growth in the Gross Domestic Product (GDP) of the country.

\subsubsection{The Exogenous Growth Theory}

The exogenous growth theory, usually referred to as the neoclassical growth theory, is considered to have been founded by Solow (1956). This theory outlines how a steady economic growth rate will be accomplished with the proper amounts of the three driving forces: labor, capital and technology. Solow (1956) showed that the rates of saving and population growth, taken exogenously by assuming a standard neoclassical production function with decreasing returns to capital, determine the steady-state level of income per capita.

\subsubsection{Endogenous Growth Theory}

The endogenous growth theory emerged due lack of response by the neoclassical theory about the reason for the different rates of economic growth among countries that have the same technological level. This theory was advanced by Romer (1990) and later supported by Stokey (1991), Grossman \& Helpman (1991), Grandy (1999), Lucas Jr. (2000), among others. According to Romer (1990), growth depends on investment in research and development. Romer (1990) adds that government action is needed to improve the efficiency of resource allocation 
through investment in human capital and encouraging private investment in high-tech industries. To Grandy (1999), the endogenous growth theory assumes that the continued growth is determined by the production process, not by outside factors, and to Lucas Jr. (2000), growth depends on savings and investment in human capital. While early neoclassical models assumed total factor productivity growth as exogenously given, the newer endogenous growth models attributed this component of growth to the "learning by doing" effect occurring between physical and human capital, which results in increasing returns to scale in production technology (Lucas Jr., 2000). The implication of endogenous growth paradigm is that policies which embrace capital formation, openness, competition, change and innovation will promote growth (Onyango \& Were, 2015). The endogenous growth economists believe that improvements in productivity bring about improvements in total production and productivity can be linked to a faster pace of innovation, inventions and extra investment in human capital.

\subsection{Review of Empirical Literature}

\subsubsection{The Role of Exogenous Growth in Explaining Economic Growth}

Physical capital accumulation, human capital accumulation and population growth are the key determinants of growth in output advanced by the neoclassical growth theory. A study by Sieng \& Yussof (2016) investigated the long term relationship between human capital and economic growth in Malaysia for the period between 1981 and 2010. The authors employed the autoregressive distributed lag (ARDL) model to analysis the relationship under study. Findings of the study indicated existence of a long run relationship between human capital and economic growth. Among all education levels, labour with high educational attainment (secondary and tertiary) contributed positively to economic growth. The study's key recommendation was further investment in higher education in order to propel Malaysia towards achieving its ambition of being recognized as a high income country.

Arshad \& Munir (2015) did a study to analyze relationship between factor accumulation and economic growth in Pakistan for the time period of 1973 to 2014 using ARDL bound testing approach to cointegration. The authors considered human capital as a core factor of production and constructed its series as average year of schooling. Real capital stock was generated on the basis of gross fixed capital formation. Their study found that human capital and real physical capital stock were highly significant and growth friendly, and their key policy recommendation was that developing countries should increase share of education and health in GDP in order to accelerate economic growth.

Using times series data of Pakistan from 1972 to 2011 with traditional inputs of human capital (measured by education enrollment and health measure), physical capital and investment growth rate as independent variables while GDP as the dependent variable, Ali, Chaudhry, \& Farooq (2012) analyze the effect of human capital formation on GDP, The authors OLS to estimate the models. The study found that human capital and physical capital have positive influence on 
GDP, whereas on the other hand growth rate of investment was not found growth friendly.

Klasen \& Lawson (2007) examined the link between population growth and per capita economic growth in Uganda. The authors used both cross-chapter and panel data. The empirical model was estimated in the framework of Harrod-Domar, Solow and Panel models. All the models were estimated by the panel OLS method. Both theoretical considerations and strong empirical evidence suggested that the currently high population growth puts a considerable break on per capita growth prospects in Uganda. Findings further revealed that population growth contributed significantly to low achievement in poverty reduction and was associated with households being persistently poor and moving into poverty.

In a study to explore physical capital and human capital complementarity impact on long-run economic growth in the selected developing countries, Najet \& Sunli (1999) employed a time series approach of Vector Autoregression (VAR). The authors took human capital data for Austria, Australia, Canada, France, Germany, Italy, Japan, Norway, Sweden, Switzerland, United Kingdom and the United States human capital data from Barro \& Lee (1993) data set. Physical capital stock data was taken from Nehru \& Dhareshwar (1993) and GDP data from World Bank (1994) International Statistics. The VAR results confirmed that physical capital and human capital complementarity is a good proxy in explaining GDP growth for selected developed countries.

Mankiw, Romer and Weil in 1992 studied the role of Factor accumulation in the framework of the Augmented Solow Growth model in explaining international variations in income. The authors used time series data for the period 1960-1985. Three samples were considered by the authors: One consisting of 98 countries excluding oil producers, the second one consisted of countries that exclude those whose data received grade " $D$ " from Summers and Heston or whose populations in 1960 were less than one million, and the third sample consisted of 22 OECD countries with populations greater than one million. The empirical models were log transformed and estimated using OLS. Results showed both human capital and physical capital were important in explaining international variation in growth rate in GDP per capita.

Other earlier studies who studied the causal connection between human capital and economic growth included, among others: Barro (1991) who in his study concluded that the growth rate of real per capita GDP is positively related to initial human capital; Levine \& Renelt (1992) who find that secondary school enrolment rates are positively correlated with economic growth; Barro \& Sala-i-Martin (1995) who found that the average years of schooling of both males and females in secondary and higher education are significantly correlated with GDP per capita growth rates.

\subsubsection{The Role of Endogenous Growth Theory in Explaining Economic Growth}

The endogenous growth theory is based on the premise higher levels of eco- 
nomic growth emanate from improvements in productivity through technological progress and improvements in efficiency. Literature documents several factors that increase levels of output through productivity. Some of these determinants include a faster pace of innovation, inventions, extra investment in human capital, macroeconomic environment, openness, financial deepening, demographic characteristics, technological transfer, cost of capital and other factors. Below is a review of selected empirical studies on the relationship between endogenous growth factors and economic growth.

Barro (1995) used data for period 1960 to 1990 from 100 countries to assess the effects of inflation on economic performance. The annual inflation rates were computed from consumer price indices and from the GDP deflator whenever data on consumer price indices were unavailable. The author used instrumental variables estimation to estimate a system of three regression equations. The major finding of the study was that the estimated effects of inflation on growth and investments were significantly negative, with clear evidence that the adverse effects of inflation came from experiences of high inflation. Barro (1995) noted that when inflation is not high, its negative effects on growth are relatively small. For instance, from his findings, an increase in average inflation by 10 percent per year lowers the average growth rate in GDP per capita by $0.2-0.3$ percent. The negative effect of inflation on economic growth has been reported by other authors. For instance, a study by Andrés \& Hernando (1999) on whether inflation harms economic growth with evidence from the OECD concluded that current inflation has never been found to be positively correlated with income per capita over the long run; In the study by Ahmed \& Mortaza (2005) to explore the present relationship between inflation and economic growth in the context of Bangladesh using annual data set on real GDP and CPI for the period of 1980 to 2005 with estimations by co-integration and error correction models, the study's results demonstrated that there exists a statistically significant long-run negative relationship between inflation and economic growth. Other authors who have found a negative relationship between inflation and growth include Faria \& Carneiro (2001), Harris \& Mátyás (2001), Sweidan (2004), Chaturvedi et al. (2009) and Alexander (2010) and others. There are however other authors who have found a positive relationship between inflation and economic growth. For instance, Mallik \& Chowdhury (2001) found evidence of a long-run positive relationship between GDP growth rate and inflation for all four countries of Bangladesh, India, Pakistan and Sri Lanka; Pollin \& Zhu (2006) in their study using new nonlinear regression estimates of the relationship between inflation and economic growth for 80 countries over the 1961-2000 period for middle-income and low-income countries found that higher inflation is associated with moderate gains in gross domestic product growth up to a roughly $15-18$ percent inflation threshold. The study by Bruno \& Easterly (1998) which examined the relationship between inflation and economic growth for 127 countries between 1960 and 1992 concluded that there was no robust evidence de- 
monstrating a trade-off between output growth and inflation. Other studies which have documented a positive relationship between inflation and economic growth include Sattarov (2011), Osuala et al. (2013) and others.

The relationship between trade openness and economic growth is ambiguous from both theoretical and empirical point of view (Silajdzic \& Mehic, 2017). On one hand, some studies have found that less openness through trade restrictions can promote growth (e.g. Yanikkaya, 2003; Rodriguez \& Rodrik, 2000). On the other hand, some studies have found that countries that are less open with more trade restrictions restrict growth-which means that countries that are more open promote growth. Trade openness facilities a faster movement of capital and technological transfers (Adhikary, 2011). In support of the evidence that trade openness plays an important role in economic growth, Wacziarg \& Welch (2008) showed that by the year 2000, $73 \%$ of world economies had opened up to international trade compared to $22 \%$ in 1960. Sachs \& Warner (1997) argued that economies that are more open to trade experience faster income convergence compared to closed economies. Harrison \& Hanson (1999) find a significant and negative effect of tariff rates on economic growth. A study by Huchet-Bourdon, Le Mouel, \& Vigil (2017) confirm that countries are more open in exporting higher quality products and new varieties grow more rapidly.

Al Mamun (2018) conducted a study to investigate the relationship between domestic credit and economic growth for Bangladesh economy. Sample data was taken for the period 1975-2016. Estimations were done by the method of autoregressive distributed lag (ARDL). The study found that an increase in real domestic credit impacts positively on real GDP and the impact is found to be statistically highly significant. Previous authors such as Schumpeter (1911), Goldsmith (1959), Patrick (1966) and McKinnon (1973) argue that efficient mobilization of financial intermediaries can impact technological innovation and development which ultimately transfer to higher productivity and economic growth. In another related study, King \& Levine (1993) found that current and future rates of economic growth are strongly influenced by financial development. A study by Dhungana (2014) found the existence of a long-run association between GDP, broad money (M2) and domestic credit to private sectors in respect to Nepalese economy. Lenka (2015) used Indian time series data covering the period from 1980 to 2011 and applied Autoregressive Distributed Lag (ARDL) bound testing approach to cointegration and Error Correction Model (ECM) for long-run and short-run causality between financial development and economic growth. His study found that that the financial development indicator is one of the long-run determinants of economic growth, but economic growth cannot impact financial development. A related study by Adu, Marbuahand Mensah (2013) to investigate the long-run growth effects of financial development in Ghana found that both total domestic credit to GDP ratio and private sector credit to GDP ratio have a significant impact on output growth. Rahman (2004) also found a long run relationship between domestic credit and economic growth. 
Contradicting results were reported in a study by Bongini et al. (2017) who focused on the role of financial development in the economic growth of Central, Eastern and South-Eastern European countries in the post-communist era (1995-2014) and found that bank credit does not foster economic growth.

Literature also documents mixed findings on the relationship between lending interest rate and growth in output. For instance, Al Mamun (2018) findings show that real lending rates are negatively related to the real GDP for all sample and sub-sample periods. Using annual data from 2003 to 2012, Mutinda (2014) investigated the effect of lending interest rate on economic growth in Kenya. The study established that there is a negative relationship between interest rate and the economic growth. Akinwale (2018) examined the relationship between bank lending and economic growth in Nigeria between 1980 and 2016 and concluded that a decreased in bank lending rate increased economic growth during the study period. The study by Tridico (2007) found that low bank lending rate stimulate economic growth in Nigeria. Similar studies on Nigeria reported the same findings (e.g. Nicholas, 2010; Obamuyi \& Olorunfemi, 2011 and others). Other authors who have established an inverse causal connection between lending interest rates and economic growth include; Giovanni \& Shambaugh (2008), Agu (1988), among others.

A number of studies have linked economic growth rates of nations to foreign direct investments (FDI). For developing countries, FDI inflows are often seen as an important catalyst for economic growth. In the traditional framework, FDI is expected to directly affect economic growth since FDI is assumed to complement domestic investments, it supplements for capital and investment shortages, contributes to growth through knowledge spillovers and through technological and innovative efforts. According to Fadhil and Almsafir (2015), FDI inflows together with the human capital development contribute strongly to the host country's economic growth.

Many empirical studies have therefore reported a positive causal influence of FDI on economic growth. Take for instance a study by Sokang (2018) which investigated the impact of FDI on the economic growth of Cambodia by utilizing the time series data throughout 2006-2016. The study conducted multiple regression analysis to determine the relationship between foreign direct investment and economic growth in Cambodia and found that FDI had a positive impact on the economic growth. Ford, Rork \& Elmslie (2008) found that FDI has a greater impact on per capita output growth than domestic investment for Unites states that met a minimum human capital threshold. In a study on China, Zhang (2001) provided an empirical assessment and found that FDI seems to help China's transition and promote income growth. A study by Hussain \& Haque (2016) revealed that there was a positive relationship between foreign direct investments and growth rate of per capita GDP in Bangladesh. Har, Teo, \& Yee (2008) conducted a study on the relationship between FDI and economic growth in Malaysia and found that there was a significant relationship between eco- 
nomic growth and foreign direct investment inflows in Malaysia. In other studies, the effect of FDI on growth has shown mixed outcomes but the effect remains positive. For instance, Alvarado, Iñiguez, \& Ponce (2017) found that FDI had a positive and significant effect on growth in high-income countries, while in upper-middle-income countries the effect is uneven and non-significant.

\subsection{A Review of Literature on Uganda's Growth Determinants}

Obwona (2002) did a study to investigate the FDI-growth linkage in Uganda. The author used both primary and secondary data in his study. Specifically, the author used secondary time series annual data for a period 1975-1991 to estimate the empirical model. The primary data collected by use of questionnaires was used to obtain insights regarding the perceptions of investors and how their decisions and decision-making processes were undertaken. To get rid of endogeneity bias likely to be present in the empirical growth function, the author employed a two-stage least squares (2SLS) estimation method to estimate the model. Results indicated that FDI had a positive impact on GDP growth in Uganda.

Deininger \& Okidi (2003) used household-level data from Uganda's 1992 and 1999/2000 National household Surveys respectively to study the determinants of growth and poverty in Uganda for the period 1992-2000. The authors used a tobit model for estimation of the empirical growth model. The key results from the study was that the high elasticity of both income growth and poverty reduction with respect to agricultural output (coffee) prices confirms the benefits from Uganda's decisive liberalization of output markets.

In a study funded by the World Bank entitled "Gender and Economic growth in Uganda, Unleashing the Power of Women”, Ellis, Manuel \& Blackden (2006) conducted an exploratory study on the role of Gender on economic growth in Uganda. The study was carried out at the request of the Minister of Finance, Planning and Economic Development for Uganda at the time, because the government was concerned that the specific challenges facing women had not been fully addressed in existing work on Uganda's investment climate at the time. The major sources of data and information for the study ware mainly through consultation with country office staff, client stakeholders and development partners, field assessments and workshops as well as literature review of the reports from the World Bank's Doing Business in 2005 (World Bank, 2005a), the World Bank's Strategic Country Gender Assessment (World Bank, 2005b) of Uganda, and the African Development Bank's Multi-Sector Country Gender Profile. The findings of the study indicated the considerable potential for economic growth if Uganda was to unleash the power of women and support their full economic participation in the private sector.

Leliveld (2008) launched a study to compare Uganda and Cambodia on sources growth accelerations. The study addressed two questions: 1) what are the main determinants behind the growth accelerations in both countries and 2) 
how sustained were and are the growth accelerations. Among other finding was that: a) both Uganda and Cambodia were at the variance to the general pattern of growth acceleration that is associated with post-conflict countries in which immediately after the end of the conflict there will be high growth from a low base carried to a large extent by external support, b) Both countries faced a period of authoritarian rule and civil strife and that gives the second turning point, c) Political stability returned in both countries after authoritarian rulers that allowed a certain amount of democratic control came to power.

Another study by Didas (2017) investigated the factors that affect economic growth of Uganda. The author used time series data beginning from 1994 to 2016. Emphasis was put to examine the relationship between natural resource use, inflation rate, technological growth, Terms of Trade, population growth and economic growth. The study employed a linear regression and used OLS to establish a relationship between the independent variables and the dependent variable. The findings revealed that all the independent factors listed above did not have any significant relationship with GDP. But it was also found out that population rate had the highest positive correlation relationship with GDP.

More recently, Kenganzi (2018) investigated factors influencing Uganda's economic growth measured by real Gross Domestic Product. The author estimated a linear regression linking Real GDP to independent variables which included FDI, FDI volatility, government expenditure, Money supply and trade openness. Data was quarterly spanning from 1985-1993. The empirical model was estimated by ARDL modeling procedure. Results showed that Trade openness and money supply had a positive and significant effect on economic growth whereas foreign direct investment inflows, foreign direct investment volatility and government expenditure had a negative effect.

From the empirical literature reviewed there is evidence that a limited number of studies have been done to examine Uganda's sources of economic growth, and the few that exist have focused on investigating Uganda's growth drivers for purposes of deriving policy directions. In this study, we extend the research purpose by not only focusing on policy implications but also testing theoretical economic theory. There is also a concern that many of the authors who have studied sources of Uganda's growth determinants save Obwona (2002) have not taken into account the issue of endogeneity bias inherent in growth model. This study attempts to bridge the gaps in literature by benchmarking the neoclassical growth theory in investigating Uganda's growth determinants and using a blend of growth theories in order to more understand the growth determinants for Uganda.

\section{Methodology}

\subsection{Research Design}

The study adopts a causal relationship research design. Time series econometric 
techniques are employed to study the underlying relationship between the variables under study.

\subsection{Data and Data Sources}

The study compiled time series (annual data) secondary data from the Uganda Bureau of Statistics (UBOS), Bank of Uganda (BoU) and the World Bank Development Indicators (WBDI). In the analysis, the study used Eviews software to convert the "low frequency" time series data to "high frequency" quarterly data by the method of quadratic-match average. This conversion was done to guarantee limited loss of degrees of freedom in the regression analysis, and to obtain a clearer picture of data behavior in the trend analysis.

\subsection{Model Specification and Variable Measurement}

The empirical model is specified at two levels: 1) First, the model is specified in the framework of the neoclassical model of Solow (1956) and its extension by Mankiw, Romer \& Weil (1992) in which the traditional production inputs of physical capital, labour and human capital as well as the population growth variable are the key independent variables of the model, 2) The specification in 1) is extended to capture the growth variables suggested by the endogenous growth theory. Endogenous growth theory identifies factors on which the Solow residual (Total Factor Productivity) may depend (Rao, 2006). These are fundamentally the productivity factors.

We augment the Cobb-Douglas production function with constant returns to capital and labour but with exogenous technology:

$$
Y_{t}=A f\left(K_{t}, L_{t}, H_{t}\right)
$$

where, $Y$ is output, $A$ is the exogenous technology coefficient, $K$ is the physical capital input, $L$ is the labour input and $H$ is human capital input.

In non-linear form, Equation (1) can be re-written as:

$$
Y_{t}=A K_{t}^{\alpha} L_{t}^{\beta} H_{t}^{(1-\alpha-\beta)}
$$

Following Solow (1956) and Mankiw, Romer \& Weil (1992), we introduce the population growth rate $(n)$ in the output function, which is adjusted for exogenous rate of technological progress $(g)$ and depreciation of physical capital $(\delta)$. While transforming the input variables in per worker terms, we adopt the variable notation used in the empirical analysis and modify Equation (2) as:

$$
g d p p w_{t}=A(g k f p w)^{\alpha}(h c a p p w)^{\beta}(n+g+\delta)^{\theta} e^{\varepsilon}
$$

where: $g d p p w$ is GDP per worker, $g k f p w$ is gross capital formation per worker, $h$ cappw is human capital per worker, $e$ is the Euler's number, $\alpha, \beta, \theta$ are constants and $\varepsilon$ is the residual.

With reference to Equation (3), we take a log transformation of Equation (3) and specify a linear dynamic growth model for Uganda within the neoclassical growth framework as: 


$$
\begin{aligned}
\log (\text { gdppw })_{t}= & A_{0}+\alpha_{1} \log (\text { gdppw })_{t-1}+\cdots+\alpha_{k} \log (g d p p w)_{t-k} \\
& +\beta_{1} \log (g c f p w)_{t}+\beta_{2}(\text { hcapp } w)_{t}+\beta_{3} \log (n+g+\delta)_{t}+\varepsilon
\end{aligned}
$$

where; $\log (g d p p w)_{t}$ is the logarithm of GDP per worker at time, $t$; $\log (g d p p w)_{t-k}$ are the lags of the logarithm of GDP per worker; $\log (g c f p w)_{t}$ is the logarithm of gross fixed capital formation per worker at time, $t$ which is used as a proxy for investment in physical capital; (humcappw) $t_{t}$ is the logarithm of human capital per worker at time, $t$ which is measured by total investment expenditure on education per capita, $\log (n+g+\delta)$ is the logarithm of population growth which is adjusted for exogenous technological progress and exogenous rate of depreciation of capital, and according to Mankiw, Romer \& Weil (1992) and Ding and Night (2008), $(g+\delta)=0.05$.

As previously said, the model in (4) is specified in the framework of the neoclassical growth theory as advanced by Solow (1956) and extended by Mankiw, Romer, \& Weil (1992). Some scholars in growth literature have however criticized this growth model building (e.g. Jones, 1995; Romer, 1986; Lucas Jr., 1988; among others) on the grounds of its rigid assumption of CRS and the notion of conditional convergence. We then attempt to make adjustments in model specification to incorporate advancements of the endogenous growth theory. Proponents of the endogenous growth theory argue that this growth theory is superior because of its underlying optimization characteristics based on the microeconomic foundations (Rao, 2006). Endogenous growth paradigm advances the role of productivity factors in the growth process which are captured by parameter, A in Equations (1) and (2).

Recalling Equation (3), and building on fundamentals of endogenous growth theory in combination with empirical studies, the parameter, A is a function of such variables as Inflation, domestic credit to the private sector, Openness, financial deepening, lending interest rates, FDI and other productivity variables. We then modify Equation (4) to incorporate the endogenous growth variables and write a linear dynamic growth model for empirical analysis as follows:

$$
\begin{aligned}
\log (\text { gdppw })_{t}= & \alpha_{1} \log (\text { gdppw })_{t-1}+\cdots+\alpha_{k} \log (\text { gdppw })_{t-k}+\beta_{1} \log (\text { gcfpw })_{t} \\
& +\beta_{2} \log (\text { hcapp } w)_{t}+\beta_{3} \log (n+g+\delta)_{t}+\beta_{4}(\text { inf })_{t} \\
& +\beta_{5}(\text { domcred })_{t}+\beta_{6}(\text { open })_{t}+\beta_{7}(\text { findeep })_{t} \\
& +\beta_{8}(\text { lr })_{t}+\beta_{9} \log (\text { fdi })_{t}+\varepsilon_{t}
\end{aligned}
$$

where: Inf is the annual headline inflation rate, domcred is domestic credit to the private sector, open is openness which is measured by sum of exports to imports divided by GDP, findeep is financial deepening measured by broad money divided by GDP, $l r$ is the lending interest rate, $f d i$ is foreign direct investment and $\varepsilon$ is the error term.

\subsection{Data Analytical Procedures}

We pay attention to modeling challenges associated with time series data commonly encountered empirical analysis for instance, non-stationarity of variables, 
multicollinearity, feedback effects, non-normality of the dependent variable and auto-correlation. Some of the modelling challenges are related to data behavior and others are post-estimation technicalities. To ensure that the data meets the assumptions of the method chosen to estimate the model and that model estimates are plausible, we conduct relevant pre-estimation diagnostics and post estimation diagnostic tests.

\subsubsection{Multicollinearity Test}

Multicollinearity is the existence of linear relationships between the independent variables. Multicollinearity becomes a problem in modeling multivariate regressions when the correlation coefficient between the independent variables exceeds \pm 0.8 , and the particular independent variable causing the problem would have a variance inflation factor (VIF) of 10 and above. To check for multicollinearity, we generated a correlation matrix of the independent variables and computedVariance Inflation Factors (VIFs) of the independent variables after the IV-GMM estimation.

\subsubsection{Unit Root Tests}

Unit root tests examine the stationarity of data before the relationship between explanatory and the explained variables is estimated. This is an important step to carry out in time series regressions to avoid cases of spurious regressions in case non-stationary variables are regressed on other non-stationary variables with no cointegrating relationships between the variables being studied. Non-stationarity of variables implies that the means and variances of the variables always change with time. The Augmented-Dickey-Fuller (ADF) test procedure is employed to test for unit roots.

The ADF test procedure requires estimating an equation of the form:

$$
\Delta Y_{t}=\beta_{0}+\beta_{1} Y_{t-1}+\beta_{2} t+\sum_{i=1}^{p} \alpha_{i} \Delta Y_{t-i}+\varepsilon_{t}
$$

and the hypothesis: $\mathrm{H}_{0}: \quad \beta_{1}=0$ is tested against $\mathrm{H}_{1}: \quad \beta_{1}>0$.

where, $Y_{t}$ is a vector for all-time series variables under consideration in the model; $t$ is a time trend variable; $\Delta$ denotes the first difference operator; $\mathcal{E}_{t}$ is the error term; $p$ is the optimal lag length of each variable chosen such that first-differenced terms make $\varepsilon_{t}$ white noise.

The ADF test is principally concerned with the estimate of $B_{1}$, that is, the study tests the hypothesis that $\beta_{1}=0$. The rejection of the null hypothesis in favor of the alternative hypothesis implies that $Y_{t}$ is stationary and integrated of order zero, $\mathrm{I}(0)$. Whenever the null hypothesis is rejected, the first difference is also tested for stationarity and if it stationary, the variable is integrated of order one, that is, I(1) (Johansen, 1988; Maddala, 1977; Adenutsi \& Yartey, 2007).

\subsubsection{Cointegration Test}

After checking the stationarity of all the variables in the empirical model, we proceeded with a cointegration test among the series in the model. Having established that the model variables have mixed orders of integration, we use the 
Pesaran, Shin, \& Smith (2001) ARDL bounds cointegration test that allows variables with a mix of $\mathrm{I}(0)$ and $\mathrm{I}(1)$ orders of integration. The purpose of the Pesaran et al. (2001) cointegration test is to determine whether a group of stationary series as well as a group of non-stationary series in the empirical model arecointegrated or not.

\subsubsection{Normality Test}

The study uses the skewness and kurtosis test for normality on the dependent variable. This is because regression analysis involving least squares estimation is based on the normality assumption of the dependent variable, which portrays the same distribution as the residuals from the regression. The skewness and kurtosis test for normality tests the null and alternative that data on the dependent variable follows a normal distribution against the alternative hypothesis that data on the dependent variable does not follow a normal distribution. The null hypothesis is rejected if the probability of skewness, the probability of kurtosis and the chi-square probability are less than 0.05 .

\subsubsection{Test for Endogeneity of the Independent Variables}

The study uses the Sargan test (Sargan, 1958) in to check if there are any independent variables in the empirical model that are endogenously determined. The Sargan test uses the Sargan C-statistic. The Sargan C-statistic in this case tests the null hypothesis that the associated independent variable is exogenous. The null hypothesis is rejected if the reported p-value corresponding to the Sargan $\mathrm{C}$-statistic is statistically significant at 5 percent level of significance.

\subsubsection{Test for Validity of Instruments in the IV-GMM Regression}

To avoid the possibility of over identifying restrictions that may cause instrument proliferation, the study implements the Hansen test (Hansen, 1982) which reports the Hansen J Chi-square statistic and its associated probability value. This procedure tests the null hypothesis that there are no over identifying restrictions and hence the instruments used in estimation are valid and appropriate. The null hypothesis is rejected if the associated reported p-value is less than significance level, which is 0.05 .

\subsubsection{Control of Serial Correlation}

Having time series data being utilized in the empirical modeling, the study controls for serial correlation in the residuals by estimating the empirical models by including the option "vce robust" in the STATA command when estimating the empirical model. With this option in the IV-GMM estimation, the standard errors reported are robust to serial correlation.

\section{Results}

\subsection{Descriptive Statistics on the Variable under Study}

The study summarizes the descriptive statistics of the variable under study, that is, growth rate in GDP. The descriptive statistics are presented both in table 
form and graphical form. Table 1 gives the mean, the minimum, the maximum, the standard deviation, coefficient of skewness, coefficient of kurtosis and probability of the Jarque-Bera statistic on the growth rate in GDP, which is the variable under study. Figure 2 displays the trends in Uganda's growth rate in GDP over the study period.

The descriptive statistics in Table 1 shows that over the study period, Uganda registered an average annual growth rate of 5.95 percent. The minimum growth rate in GDP was 2.91 (this was recorded in 2012q4) and the maximum rate of growth in GDP was 9.8 percent (this was recorded in 2011q2).

The normality assumption on the dependent variable: The Jarque-Bera probability tests the normality of the variable under study (i.e. growth rate in GDP). The Jarque-Bera test matches the skewness and kurtosis of data to see if it matches a normal distribution. In this study, the null hypothesis is that the sample data on growth rate in GDP is normally distributed against the alternate hypothesis is that it not normally distributed. The Jarque-Bera probability value of 0.1449 shown in Table 1 which exceeds 0.05 implies that the null hypothesis is not rejected. This suggests that the sample data on growth rate in GDP used for empirical analysis is normally distributed.

Table 1. Descriptive statistics of the growth rate in GDP for Uganda (2007q1-2008q4).

\begin{tabular}{ccccccc}
\hline Mean & Minimum & Maximum & $\begin{array}{c}\text { Std. } \\
\text { Deviation }\end{array}$ & Skewness & Kurtosis & $\begin{array}{c}\text { Jarque-Bera } \\
\text { probability }\end{array}$ \\
\hline 5.95 & 2.91 & 9.80 & 1.98 & 0.4671 & 1.9710 & 0.1449 \\
\hline
\end{tabular}

Source: Generated by the author from raw data.

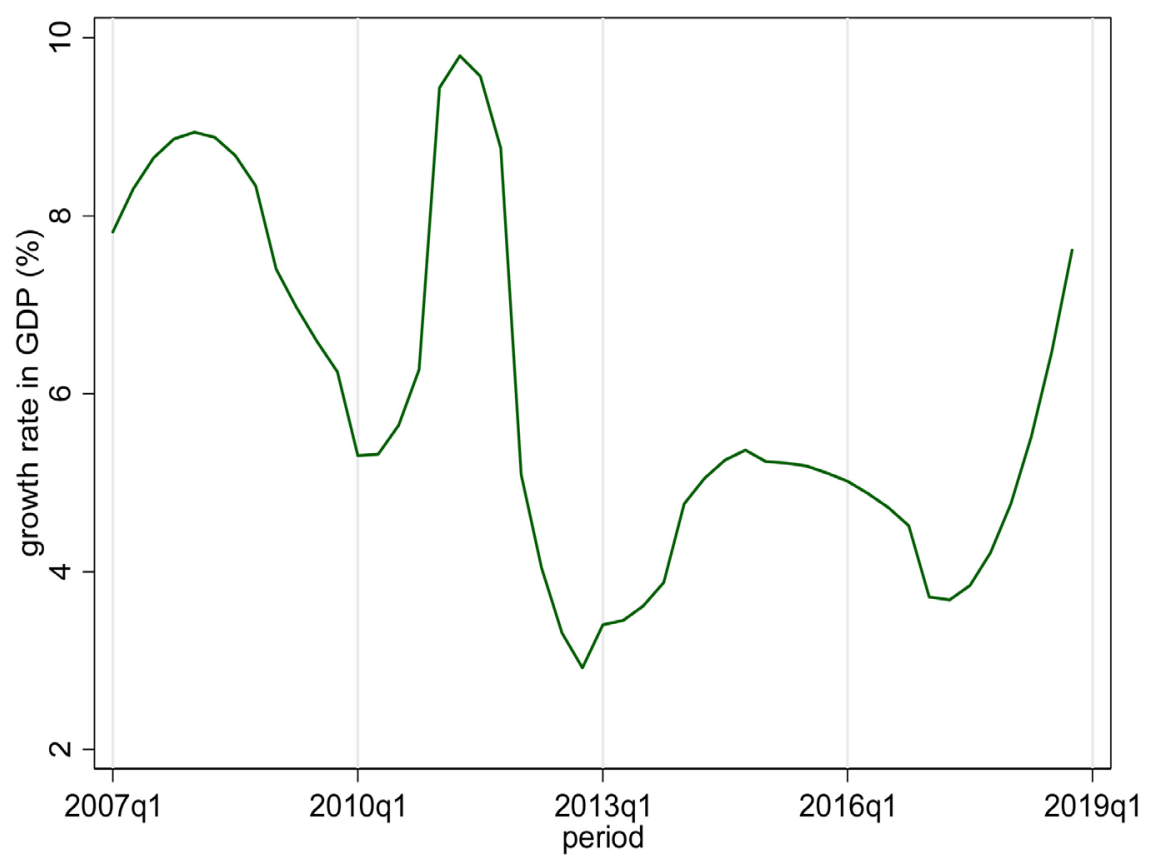

Figure 2. Trends in the growth rate in GDP for Uganda (2007q1-2018q4). Source: Generated by the authors from raw data using STATA. 
Figure 2 shows that Uganda has recorded remarkable variations in quarterly growth rate in GDP over the study period. The trend shows that the quarterly growth rate in GDP started rising from 2007q1 up to 2008q1. It then started declining from 2008q2 up to 2010q1. A recovery was then registered from 2010q2 which peaked in 2011q2. Again there was some recession from 2011q2 which peaked in 2012q4. Some moderate recovery was registered from 2013q1 to around 2015q3. The economy again slowed down from $2015 q 4$ to $2017 q 3$, and then rebounded from $2017 \mathrm{q} 4$ to around $2018 \mathrm{q} 4$.

\subsection{Stationarity Tests on All Model Variables}

The study employs the Augmented-Dickey-Fuller (ADF) test to test the stationarity of the variables. Lag lengths in the stationarity tests is chosen automatically by the Akaike Information Criteria (AIC).

The unit root test results summarized in Table 2 indicate that the logarithm of human capital per worker and inflation variables are stationary in levels, that is, they are $\mathrm{I}(0)$. On the other hand, the unit root test results in Table 2 indicate that logarithm of GDP per worker, logarithm of gross fixed capital formation per worker, population growth, domestic credit, openness, financial deepening, lending interest rate and logarithm of FDI are non-stationary in levels but become stationary in first difference, that is, they are I(I). The unit root test results thus indicated a mix of $\mathrm{I}(0)$ and $\mathrm{I}(1)$ variables in the growth model under study.

Table 2. Unit root tests on all the model variables.

\begin{tabular}{|c|c|c|c|c|c|}
\hline Variable & $\begin{array}{l}\text { ADF Z-stat. } \\
\text { in level }\end{array}$ & $\begin{array}{l}\text { MacKinnon } \\
\text { approximate } \\
\text { p-value for } \\
\mathrm{Z}(\mathrm{t})\end{array}$ & $\begin{array}{l}\text { ADF Z-stat. } \\
\text { in first diff. }\end{array}$ & $\begin{array}{l}\text { MacKinnon } \\
\text { approximate } \\
\text { p-value for } \\
\mathrm{Z}(\mathrm{t})\end{array}$ & $\begin{array}{l}\text { Order of } \\
\text { Integration }\end{array}$ \\
\hline logarithm of GDP per worker & -1.565 & 0.5014 & $-3.427^{\star \star}$ & 0.0101 & $\mathrm{I}(\mathrm{I})$ \\
\hline $\begin{array}{l}\text { logarithm of gross fixed capital } \\
\text { formation per worker }\end{array}$ & $-2.657^{\star}$ & 0.0817 & $-5.790^{\star * \star}$ & 0.0000 & $\mathrm{I}(1)$ \\
\hline $\begin{array}{l}\text { logarithm of human capital } \\
\text { per worker }\end{array}$ & $-3.743^{\star * *}$ & 0.0035 & - & - & $\mathrm{I}(0)$ \\
\hline population growth & -2.976 & 0.1388 & -4.071 & 0.0011 & $\mathrm{I}(1)$ \\
\hline inflation & $-3.127^{\star *}$ & 0.0246 & - & - & $\mathrm{I}(0)$ \\
\hline domestic credit & -2.377 & 0.1483 & $-3.692^{\star * *}$ & 0.0042 & $\mathrm{I}(1)$ \\
\hline openness & -1.329 & 0.6158 & $-3.923^{\star * *}$ & 0.0019 & $\mathrm{I}(1)$ \\
\hline financial deepening & 0.673 & 0.9893 & $-4.771^{\star \star *}$ & 0.0001 & $\mathrm{I}(1)$ \\
\hline lending interest rate & $-2.717^{\star}$ & 0.0712 & $-3.635^{\star * *}$ & 0.0051 & $\mathrm{I}(1)$ \\
\hline $\begin{array}{l}\text { logarithm of foreign direct } \\
\text { investment }\end{array}$ & -2.411 & 0.1386 & $-3.158^{\star *}$ & 0.0225 & $\mathrm{I}(1)$ \\
\hline
\end{tabular}

Source: Compiled by the authors. ${ }^{*}{ }^{* *},{ }^{* *}$ indicate significance at 10,5 and 1 percent levels respectively. 


\subsection{Multicollinarity Test: Pairwise Correlations between All the Independent Variables and VIF of the Independent Variables}

Having multiple independent variables in our empirical growth model, it is prudent to check for the degree of linear correlation between the independent variables in the model. It is common knowledge that high linear relationships between the independent variables (correlations in excess of \pm 0.8 ) would cause a problem of multicollinearity in the regression model. To check for the possibility of multicollinearity, we generate a correlation matrix of the independent variables to find out if there are regressors with high linear correlations. The correlation matrix is proceeded by the variance inflation factor (VIF) table which helps to identify which particular independent variables would be causing the multicollinearity problem. Table 3 shows the correlation matrix of all the independent variables and Table 4 shows the VIFs the independent variables.

The correlation matrix in Table 3 shows that all the pairwise correlation coefficients between the independent variables in the extended model are not in excess 0.8 in absolute value except the correlation coefficient between financial deepening and population growth $(r=0.930573 ; \mathrm{p}=0.000)$. Additionally, these variables (financial deepening and population growth) have high VIFs of 24.16

Table 3. Correlation matrix of all the independent variables.

\begin{tabular}{|c|c|c|c|c|c|c|c|c|c|}
\hline \multicolumn{10}{|c|}{ Correlation (Probability is under the correlation coefficient) } \\
\hline & $\operatorname{loggcfpw}$ & loghcappw & popg & $\inf$ & open & domcred & findeep & $\operatorname{lr}$ & $\operatorname{logfdi}$ \\
\hline \multirow[t]{2}{*}{$\operatorname{loggcfpw}$} & 1 & & & & & & & & \\
\hline & ----- & & & & & & & & \\
\hline \multirow[t]{2}{*}{ loghcappw } & $-0.314^{\star *}$ & 1 & & & & & & & \\
\hline & 0.030 & ----- & & & & & & & \\
\hline \multirow[t]{2}{*}{ popg } & 0.197 & $-0.258^{*}$ & 1 & & & & & & \\
\hline & 0.179 & 0.077 & ----- & & & & & & \\
\hline \multirow[t]{2}{*}{ inf } & -0.126 & 0.010 & $-0.452689^{* * *}$ & 1 & & & & & \\
\hline & 0.395 & 0.499 & 0.0012 & ----- & & & & & \\
\hline \multirow[t]{2}{*}{ open } & $-0.603^{* * *}$ & 0.011 & $-0.625983^{\star * *}$ & $0.496974^{\star * *}$ & 1 & & & & \\
\hline & 0.000 & 0.941 & 0.0000 & 0.0003 & ---- & & & & \\
\hline \multirow[t]{2}{*}{ domcred } & $0.579^{* * *}$ & $-0.464^{\star * *}$ & $0.644942^{\star * *}$ & -0.143974 & $-0.385475^{\star * \star}$ & 1 & & & \\
\hline & 0.000 & 0.000 & 0.0000 & 0.3289 & 0.0068 & ----- & & & \\
\hline \multirow[t]{2}{*}{ findeep } & $0.380^{\star * *}$ & $-0.352^{*}$ & $0.930573^{\star * *}$ & $-0.361656^{\star}$ & $-0.641363^{\star * *}$ & $0.777281^{\star \star}$ & 1 & & \\
\hline & 0.008 & 0.014 & 0.0000 & 0.0115 & 0.0000 & 0.0000 & ----- & & \\
\hline \multirow[t]{2}{*}{$\operatorname{lr}$} & $0.524^{* * *}$ & -0.108 & 0.024127 & $0.349185^{\star *}$ & -0.112351 & $0.347854^{\star *}$ & 0.132591 & 1 & \\
\hline & 0.000 & 0.463 & 0.8707 & 0.0150 & 0.4471 & 0.0154 & 0.3690 & ---- & \\
\hline \multirow[t]{2}{*}{ logfdi } & $0.375^{\star * *}$ & 0.180 & 0.056005 & 0.048779 & -0.219792 & 0.126858 & 0.230273 & 0.204915 & 1 \\
\hline & 0.009 & 0.221 & 0.7054 & 0.7420 & 0.1333 & 0.3902 & 0.1154 & 0.1624 & ----- \\
\hline
\end{tabular}

Source: Compiled by authors. ${ }^{*},{ }^{* *},{ }^{* *}$ indicates significance at 10,5 and 1 percent levels respectively. 
Table 4. VIFs of the independent variables in the extended model.

\begin{tabular}{ccc}
\hline Independent variables & VIF & $1 / \mathrm{VIF}$ \\
\hline financial deepening & 24.16 & 0.0414 \\
population growth & 10.01 & 0.0999 \\
logarithm of gross fixed capital formation per worker & 9.94 & 0.1006 \\
openness & 9.13 & 0.1095 \\
domestic credit & 8.19 & 0.1220 \\
Logarithm of human capital per worker & 2.57 & 0.3890 \\
Lending interest rate & 2.45 & 0.4077 \\
inflation & 2.07 & 0.4839 \\
mean VIF & 1.93 & 0.5194 \\
\hline
\end{tabular}

Source: Generated by the author after IV-GMM regression.

and 10.01 respectively as show in Table 4 . This suggests that the inclusion of both financial deepening and population growth in the same regression model may create a multicollinearity problem within the regression model. Between the two variables, we dropped financial deepening which had a much higher VIF from the empirical model. Moreover, the same variable (i.e. financial deepening) was also strongly correlated with another independent variable, that is, domestic credit $(\mathrm{r}=0.777281 ; \mathrm{p}=0.000)$.

\subsection{The Cointegration Test in the Model Specified in the Neoclassical Growth Framework}

We first test for cointegration in the specific model with variables that depicts neoclassical growth specification. Table 5 shows the PSS bounds testing for cointegration results from the Pesaran et al. (2001) bounds testing approach to cointegration.

The PSS bounds test results in Table 5 indicate that the null hypothesis is rejected for I (0) variables since the p-values of $\mathrm{F}$ and $\mathrm{t}$ statistics are not simultaneously greater than $5 \%$ significance level. On the other hand, the PSS bounds test results in Table 5 indicate that the null hypothesis is not rejected for I (1) variables since the $\mathrm{p}$-values of $\mathrm{F}$ and $\mathrm{t}$ statistics are simultaneously greater than 5\% significance level. The Pesaran et al. (2001) bounds test results suggest that there are cointegrating relations in the empirical model for the I (0) variables.

\subsection{The Cointegration Test in the Extended Model}

We also conduct acointegration in the extended model in which additional variables from the endogenous growth theory are incorporated in the empirical model. Table 6 shows the PSS bounds testing for cointegration results for the extended model.

The PSS cointegration test results in the extended model summarized in Table 6 mirror the PSS cointegration test results in Table 5 in the sense that similar to 
Table 5. PSS bounds testing for cointegration results in the specific model.

\begin{tabular}{ccccc}
\hline \multicolumn{4}{c}{ Ho: No level relationship } \\
\hline $\begin{array}{c}\text { Kripfganz \& } \\
\text { Schneider } \\
\text { statistics }\end{array}$ & $\begin{array}{c}\text { Kripfganz \& } \\
\text { Schneider } \\
(2018) \text { critical } \\
\text { values at 5\% } \\
\text { level for } \\
\text { I (0) Variables }\end{array}$ & $\begin{array}{c}\text { (2018) critical } \\
\text { values at 5\% } \\
\text { level for } \\
\text { I (1) Variables }\end{array}$ & $\begin{array}{c}\text { Approximate } \\
\text { p-value for } \\
\text { I (0) Variables }\end{array}$ & $\begin{array}{c}\text { Approximate } \\
\text { p-value for } \\
\text { I (1) Variables }\end{array}$ \\
\hline $\mathrm{F}=3.479$ & 3.428 & 4.821 & 0.047 & 0.164 \\
$\mathrm{t}=-2.996$ & -2.861 & -3.797 & 0.037 & 0.186 \\
\hline
\end{tabular}

Source: Author's compilation from STATA output. Notes: 1-Do not reject Ho if both F and t statistics are closer to zero than critical values for I ( 0 ) variables [i.e. do not reject Ho if p-values corresponding to $\mathrm{F}$ and $\mathrm{t}$ exceed the desired level for I (0) variables]. 2-rejectHo if both $\mathrm{F}$ and $\mathrm{t}$ are more extreme than critical values for I (1) variables [i.e. reject Ho if p-values are less than the desired level for I (1) variables].

Table 6. PSS bounds testing for cointegration results in the extended model.

\begin{tabular}{ccccc}
\hline \multicolumn{5}{c}{ Ho: No level relationship } \\
\hline $\begin{array}{c}\text { Kripfganz \& } \\
\text { Schneider } \\
\text { statistics }\end{array}$ & $\begin{array}{c}\text { Kripfganz \& } \\
\text { Schneider } \\
(2018) \text { critical } \\
\text { values at } 5 \% \\
\text { level for } \\
\text { I (0) Variables }\end{array}$ & $\begin{array}{c}\text { (2018) critical } \\
\text { values at } 5 \% \\
\text { level for } \\
\text { I (1) Variables }\end{array}$ & $\begin{array}{c}\text { Approximate } \\
\text { p-value for } \\
\text { I (0) Variables }\end{array}$ & $\begin{array}{c}\text { Approximate } \\
\text { p-value for } \\
\text { I (1) Variables }\end{array}$ \\
\hline $\mathrm{F}=23.639$ & 2.533 & 4.106 & 0.000 & 0.000 \\
$\mathrm{t}=-1.988$ & -2.814 & -4.661 & 0.210 & 0.741 \\
\hline
\end{tabular}

Source: Author's compilation from STATA output. Notes: 1-Do not reject Ho if both F and t statistics are closer to zero than critical values for I (0) variables. [i.e. do not reject Ho if $\mathrm{p}$-values corresponding to $\mathrm{F}$ and $\mathrm{t}$ exceed the desired level for I (0) variables]. 2-reject Ho if both $\mathrm{F}$ and $\mathrm{t}$ are more extreme than critical values for I (1) variables [i.e. reject Ho. if p-values are less than the desired level for I (1) variables.

the results in the specific model, the PSS bounds test results in Table 6 also indicate that the null hypothesis is rejected for I (0) variables since the p-values of $\mathrm{F}$ and $\mathrm{t}$ statistics are not simultaneously greater than $5 \%$ significance level, and the null hypothesis not rejected for I (1) variables since the p-values of $\mathrm{F}$ and $\mathrm{t}$ statistics are simultaneously greater than $5 \%$ significance level. The Pesaran et al. (2001) bounds test result suggest that there are cointegrating relations in the extended model for the I (0) variables.

Overall, the cointegration test results indicate that there is evidence of levels relationship in both the specific model and the extended model. The study proceeds by estimating the empirical models with un-differenced variables by the method of Instrumental Variables regression using generalize method of moments (IV-GMM). This estimation method controls for endogeneity bias, allows control of time effects, has options to control for serial correlation and heteroskedasticity of unknown form and its post estimation allows the tests for endogeneity and the over identifying restrictions. 


\subsection{Results of the Regression Model Estimated in the Neoclassical Growth Framework}

Because the logarithm of the gross fixed capital formation is endogenously determined in the empirical model and because of the presence of cointegration, the study estimates the model with un-differenced variables using the generalized method of moments (GMM) in such a way to obtain long run GMM estimates. The IV-GMM method controls for the endogeneity bias and has the ability to control for time effects. Table 7 shows the IV-GMM estimates of the empirical model which is specified in the framework of neoclassical model.

Estimates in Table 7 indicate that that the estimated coefficient on the lagged dependent variable is positive and statistically insignificant at 5 percent level of significance. This particular result suggests two things: 1) growth in GDP per worker in the current period is significantly affected by growth rate in GDP per worker in the previous period, which indicates that growth tends to be persistent. This kind persistence in growth was initially supported by Harrod (1939) and Domar (1946) who asserted that part of income in the current period in saved and the savings are used for further investment, and as a result output increases in the next period, 2) The positive coefficient on the lagged dependent variable which is statistically significant suggests that Uganda's income per capita diverges in the long run instead of converging. This result differs from the original finding of Solow (1956), Mankiw et al. (1992), Islam (1995) and others who

Table 7. The IV-GMM estimates of the growth function specified in the neoclassical growth framework.

\begin{tabular}{|c|c|c|c|}
\hline \multicolumn{4}{|c|}{ Dependent variable: Log of GDP per capita } \\
\hline Independent Variables & Coef. & $\begin{array}{c}\text { Robust } \\
\text { Std. Error }\end{array}$ & p-value \\
\hline $\log$ of GDP per capita $(\mathrm{t}-1)$ & $0.6326^{* * *}$ & 0.0039448 & 0.000 \\
\hline log of gross fixed capital formation per capita & $0.0124^{*}$ & 0.006495 & 0.055 \\
\hline log of human capital per capita & $0.0274^{\star * *}$ & 0.003163 & 0.000 \\
\hline population growth & $-0.0636^{* * *}$ & 0.011003 & 0.000 \\
\hline Constant & $1.6024^{\star * *}$ & 0.180074 & 0.000 \\
\hline \multicolumn{4}{|l|}{ Other estimates and robustness test results } \\
\hline Implied lambda $(\lambda)$ & 0.034 & - & - \\
\hline Sargan C-statistic & $3.224^{\star *}$ & - & 0.045 \\
\hline Hansen J Chi-sq. test & 39.301 & - & 0.546 \\
\hline Prob > Wald Chi2 & 0.000 & - & - \\
\hline R-squared & 0.480 & - & - \\
\hline Pr (Skewness) & 0.065 & - & - \\
\hline $\operatorname{Pr}$ (Kurtosis) & 0.071 & - & - \\
\hline Joint $\operatorname{Pr}>$ chi2 & 0.084 & - & - \\
\hline
\end{tabular}

Source: Author's compilation from stata output. ${ }^{*}{ }^{* *},{ }^{* *}$ indicate significance at $10 \%, 5 \%$ and $1 \%$ levels respectively. 
found evidence of countries' convergence to their respective long run rate of economic growth. However, the results are consistent with the findings of some related studies who have reported evidence of income divergence, for example Romer (1986), Ades \& Glaeser (1999), among others.

Estimates in Table 7 indicate the estimated coefficient on logarithm of gross fixed capital formation per capita is positive and statistically insignificant at 5 percent level of significance. This result suggests that variations in gross fixed capital formation per worker do not have a causal effect on growth rate in GDP per capita in Uganda. This result deviates slightly from the findings of Arshad \& Munir (2015) whose study revealed that real physical capital stock (measured by gross fixed capital formation) was highly significant and growth friendly. However, at 10 percent level of significance, the result more less agrees with the findings of Najet \& Sunli (1999) and Ali, Chaudhry, \& Farooq (2012) who found that physical capital had positive influence on GDP.

The estimates in Table 7 indicate that the coefficient on log of human capital per worker is positive and statistically significant at 5 percent level of significance. This result suggests that human capital per worker is an important predictor of Uganda's GDP per worker. The results of this study on how human capital influences growth in GDP tally well with the findings of a plethora of other authors for instance Sieng \& Yussof (2016), Arshad \& Munir (2015), Ali, Chaudhry, \& Farooq (2012), Najet \& Sunli (1999), Barro \& Sala-i-Martin (1995), Mankiw et al. (1992) among others. Human capital development contributes positively to economic growth because educated labor force adapts quickly to technological changes and is associated with less costs of on-job training and complements efficiently with other factors of production.

Estimates in Table 7 further show that the estimated coefficient on population growth is negative and statistically significant at 1 percent level of significance. This result suggests that growth in population constraints growth in Uganda's GDP per capita, which is consistent with predictions of Solow (1956). High population growth rate is negatively correlated with long run economic growth, especially when additional population adds on dependency burden. This is mostly true in many developing countries like Uganda, where the population pyramid depicts an inverted $\mathrm{V}$ and where the majority of the population has not attained working age status. Moreover, such countries mostly face high fertility rates, unemployment rates, infrastructural deficiencies and poor health care.

Table 7 further shows a summary of other estimates and robustness test results. We explain these as follows:

Implied lambda $(\lambda)$ : This is a measure of speed of convergence/divergence to the steady state growth rate in the estimated neoclassical growth model. Mankiw, Romer \& Weil (1992) showed that the rate of convergence is given by: $\lambda=(n+g+\delta)(1-\alpha-\beta)$. If the estimated coefficient on the initial income (the lagged dependent variable) is negative and statistically significant, then $\lambda$ will indicate convergence. If the coefficient is positive and statistically significant, then 
$\lambda$ will indicate divergence. The estimates in Table 6 indicate that the estimated coefficient on the initial income is positive and statistically significant at one percent level of significance and the estimated $\lambda=0.034$. This suggests that Uganda's income diverges at the rate of approximately 3.4 percent per quarter in the long run.

1) The Sargan C-statistic. The Sargan C-statistic tests for endogeneity of the regressors. In the GMM regression the log gross fixed capita formation was taken as an endogenous regressor. The Sargan C-statistic in this case tests the null hypothesis that log gross fixed capita formation is exogenous. The reported p-value corresponding to the Sargan C-statistic is statistically significant at 5 percent level of significance. The statistic therefore rejects the null hypothesis. This suggests that log gross fixed capita formation is an endogenous regressor in the growth function estimated in the neoclassical growth frame work.

2) The Hansen J Chi-square statistic. This is a test for presence of over identifying restrictions in the GMM estimation. The null hypothesis is that there are no over identifying restrictions. Estimates in Table 6 show that the p-value associated with the Hansen J-statistic $(\mathrm{p}=0.5463)$ is greater than 0.05 . This means that the null hypothesis is not rejected, suggesting that the instruments used are valid and appropriate.

3) Test on the normality of the residuals. Estimates summarized in Table 6 indicate a skewness probability of 0.065 , a kurtosis probability of 0.712 and a joint chi-square probability of 0.084 . The reported probabilities exceed 0.05 , suggesting that the null hypothesis that the residuals from the regression are normally distributed is not rejected at 5 percent level of significance.

\section{4) Key concluding remarks.}

The estimates of the growth function specified in the neoclassical growth framework do not fully support the predictions of Solow (1956) and results of Mankiw et al. (1992), rather the results from indicate that growth in Uganda can be fairly analyzed in the general framework of the neoclassical growth model.

\subsection{Results of the Extended Model that Incorporates Endogenous Growth}

After the estimation of the empirical model in the framework of the neoclassical growth paradigm, we extended the analysis by introducing, in the empirical model, additional growth variables proposed by the endogenous growth theory previously advanced by Romer (1990). Table 8 shows the regression estimates of the extended model.

Like with the previous estimatessummarize in Table 7, estimates of the extended growth equation summarized in Table 8 show that the estimated coefficient on the lagged dependent variable is positive and statistically insignificant at 5 percent level of significance. This suggests that even when the growth model is extended to include endogenous growth variables, the growth in GDP per worker in the current period is significantly affected by growth rate in GDP per 
Table 8. The IV-GMM estimates of the extended growth function.

\begin{tabular}{|c|c|c|c|}
\hline \multicolumn{4}{|c|}{ Dependent variable: Log of GDP per capita } \\
\hline Independent Variables & Coef. & $\begin{array}{l}\text { Robust } \\
\text { Std. Error }\end{array}$ & p-value \\
\hline logarithm of GDP per capita(t-1) & $0.6153^{* * *}$ & 0.01262 & 0.000 \\
\hline $\begin{array}{l}\text { logarithm of gross fixed capital } \\
\text { formation per worker }\end{array}$ & 0.0272 & 0.01979 & 0.455 \\
\hline logarithm of human capital per capita & $0.0380^{* *}$ & 0.01710 & 0.026 \\
\hline population growth & $-0.0139^{* *}$ & 0.00307 & 0.044 \\
\hline inflation & -0.0195 & 0.04140 & 0.604 \\
\hline openness & 0.0241 & 0.08729 & 0.783 \\
\hline domestic credit & $0.0214^{* * *}$ & 0.00137 & 0.000 \\
\hline lending interest rates & $-0.0136^{* * *}$ & 0.00131 & 0.000 \\
\hline logarithm of FDI & $0.3730^{* * *}$ & 0.07830 & 0.000 \\
\hline Constant & $0.9346^{*}$ & 0.34456 & 0.065 \\
\hline \multicolumn{4}{|l|}{ Other estimates and robustness test results } \\
\hline Sargan C-Statistic & $6.49^{* *}$ & - & 0.011 \\
\hline Hansen J Chi-sq. test & 32.08 & - & 0.610 \\
\hline Prob > Wald Chi2 & 0.000 & - & - \\
\hline $\operatorname{Pr}$ (Skewness) & 0.065 & - & - \\
\hline $\operatorname{Pr}$ (Kurtosis) & 0.712 & - & - \\
\hline Joint $\operatorname{Pr}>$ chi 2 & 0.084 & - & - \\
\hline R-squared & 0.64 & - & - \\
\hline
\end{tabular}

Source: Author's compilation from stata output. ${ }^{*},{ }^{* *},{ }^{* *}$ indicate significance at 10,5 and 1 percent levels respectively.

worker in the previous period. Also like it was in the results summarized in $\mathrm{Ta}$ ble 6, the estimates in Table 8 show that the estimated coefficient on the on logarithm of gross fixed capital formation per capita is positive and statistically insignificant at 5 percent level of significance. This coefficient is also statistically insignificant at 10 percent level. This result suggests that when additional explanatory variables from the endogenous growth theory are introduced in the model, variations in gross fixed capital formation per worker do not have a causal effect on growth rate in GDP per worker even when the significance level is raised to 10 percent. The estimates in Table 8 further indicate that, in the extended model, the coefficients on log of human capital per worker is positive and statistically significant at 5 percent level of significance, suggesting that, human capital per worker persists to be a key determinant of GDP per worker in Uganda. Estimates in the extended model as summarized in Table 8 show that the estimated coefficient on population growth is negative and statistically significant at 5 percent level of significance, suggesting that even when additional variables are introduced in the growth model, increase in population growth constraints Uganda's growth in GDP per worker. 
Results in Table 8 further indicate that the estimated coefficients on domestic credit, lending interest rate and logarithm of FDI have expected signs and are statistically significant at 5 percent level of significance. This suggests that expansion of domestic credit, low lending interest rates as well as increase in foreign direct investments have significant positive causal effect of the growth in GDP per capita in Uganda. The estimates summarized in Table 8 indicate that inflation and openness are statistically insignificant at 5 percent level, suggesting that that inflation and openness are not important factors that determine growth in GDP per worker in Uganda.

\section{Conclusion}

Using quarterly data for the period 2007 to 2018, the study investigated the relevance of the neoclassical growth model in explaining growth variations in Uganda. The specific-to-general modelling technique was employed where the growth model is first specified in the neoclassical growth framework and then extended to encompass the endogenous growth theory. The empirical growth models are estimated by the method of instrumental variable generalized method of moments.

Results show that when the empirical model is estimated in the framework of the neoclassical growth hypothesis, it provides up to 48 percent explanatory power of the total growth variations. At this level of model specification, estimates show that human capital per worker and population growth have the right signs as predicted by the neoclassical growth model and are statistically significant at 1 percent level of significance. The estimates show that the variable physical capital per worker also has the right sign but is statistically insignificant at 5 percent level. The results of model estimates in the neoclassical framework do not support the notion of conditional convergence as predicted by the neoclassical growth theory, rather the estimates show evidence of divergence. When the model is extended to include growth factors proposed by the proponents of endogenous growth hypothesis, the explanatory power of the model rises from 48 percent to 64 percent which shows improvement in model's goodness of fit by 16 percent. In the extended growth model, all the variables originally proposed in the neoclassical growth theory (i.e. physical capital per worker, human capital per worker and population growth) retain the right signs but lose their initial levels of statistical significance. The estimates show that variables such as domestic credit, lending interest, FDI, have expected signs and are statistically significant at 1 percent level of significance while openness has the expected sign but is statistically insignificant at 5 percent level of significance.

Overall, the study results do not fully reject the first null hypothesis that was set to be tested in a sense that whereas human capital per worker and population growth individually are significant growth determinants in Uganda, physical capital per worker is not. The three variables however show a significant joint casual effect on Uganda's economic growth. The results on the other hand do not reject 
the second null hypothesis that was set to be tested in this study in the sense that the results in this study did not support the neoclassical notion of conditional convergence. In a nut shell, results show that Uganda's growth determinates can be fairly but not fully modelled within the general framework of the neoclassical growth theory. Estimates therefore indicate a fractional relevance of the neoclassical growth theory in explaining growth determinants in Uganda for the study period considered in this study.

\section{Policy Recommendations}

We develop the recommendations arising from the study on the basis of the key study variables, which have been basically motivated by the theoretical model, that is, the neoclassical growth model. In essence the study has been designed to test theory. However, we consider the estimates from the study and benchmark the key study variables motivated by the adopted theory to build the recommendations. We therefore summarize the key policy recommendations derived from the study are as follows:

To enhance the rate of economic growth in Uganda, it seems prudent for Ugandan policy makers to enhance investments in human capital which can be achieved by earmarking extra resources/increase budget allocation for extra investments in education and training (i.e. enhance human capital development). Secondly, it appears that increase in Uganda's population creates bigger burden on national resources due to higher dependency. Uganda exhibits an expansive population pyramid in which the largest proportion is the young population, which again reflects high fertility rate. Such demographic trend is associated with low productivity. Consequently, we recommend deliberate efforts by Ugandan government to control population growth rate in order to save resources which can be invested to boost the rate of growth of Uganda's GDP.

\section{Conflicts of Interest}

The authors declare no conflicts of interest regarding the publication of this paper.

\section{References}

Adenutsi, D. E., \& Yartey, C. A. (2007). Financial Sector Development and Macro-Dynamics of De Facto Dollarization in Developing Countries: The Case of Ghana. West African Journal of Monetary and Economic Integration, 7, 49-90.

Ades, A. F., \& Glaeser, E. L (1999). Evidence on Growth, Increasing Returns, and the Extent of the Market. The Quarterly Journal of Economics, 114, 1025-1045. https://doi.org/10.1162/003355399556205

Adhikary, B. K. (2011). FDI, Trade Openness, Capital Formation, and Economic Growth in Bangladesh: A Linkage Analysis. International Journal of Business and Management, 6, 16-28. https://doi.org/10.5539/ijbm.v6n1p16

Adu, G., Marbuah, G., \& Mensah, J. T. (2013). Financial Sector Development and Economic Growth in Ghana: Does the Measure of Financial Development Matter? Review 
of Development Finance, 3, 192-203. https://doi.org/10.1016/j.rdf.2013.11.001

Aghion, P., \& Howitt, P. (1992). A Model of Growth through Creative Destruction. Econometrica, 60, 323-351. https://doi.org/10.2307/2951599

Agu, C. C. (1988). Nigerian Banking Structure and Performance: The Banking System's Contribution to Economic Development. Onitsha: Africana-FEP Publishers.

Ahmed, S., \& Mortaza, M. G. (2005). Inflation and Economic Growth in Bangladesh: 1981-2005. Working Paper Series: WP0604, Dhaka, Bangladesh: Research Department, Bangladesh Bank.

Akinwale, S. O. (2018). Bank Lending Rate and Economic Growth. Evidence from Nigeria. International Journal of Academic Research in Economics and Management Sciences, 7, 111-122. https://doi.org/10.6007/IJAREMS/v7-i3/4440

Al Mamun, M., S. (2018). Does Domestic Credit of the Banking Sector Promote Economic Growth? Evidence from Bangladesh. International Journal of Islamic Business, 3, 33-55.

Alexander, W. R. J. (2010). Inflation and Economic Growth: Evidence from a Growth Equation. Applied Economics, 29, 233-238. https://doi.org/10.1080/000368497327290

Ali, S., Chaudhry, I. S., \& Farooq, F. (2012). Human Capital Formation and Economic Growth in Pakistan. Pakistan Journal of Social Sciences, 32, 229-240.

Alvarado, R., Iñiguez, M., \& Ponce, P. (2017). Foreign Direct Investment and Economic Growth in Latin America. Economic Analysis and Policy, 56, 176-187. https://doi.org/10.1016/j.eap.2017.09.006

Andrés, J., \& Hernando, I. (1999). Does Inflation Harm Economic Growth? Evidence from the OECD. In M. Feldstein (Ed.), The Costs and Benefits of Price Stability (pp. 315-348). Chicago, IL: University of Chicago Press.

Anidiobu, G. A., Okolie, P. I. P., \& Oleka, D. C. (2018). Analysis of Inflation and Its Effect on Economic Growth in Nigeria. IOSR Journal of Economics and Finance, 9, 28-36.

Arshad, S., \& Munir, K. (2015). Factor Accumulation and Economic Growth in Pakistan: Incorporating Human Capital. International Journal of Social Economics, 45, 480-491. https://doi.org/10.1108/IJSE-12-2016-0346

Barro, R. J. (1991). Economic Growth in a Cross-Chapter of Countries. Quarterly Journal of Economics, 106, 407-443. https://doi.org/10.2307/2937943

Barro, R. J. (1995). Inflation and Economic Growth. NBER Working Paper Series No. 5326, Cambridge, MA: NBER. https://doi.org/10.3386/w5326

Barro, R. J., \& Lee, J. W. (1993). Losers and Winners in Economic Growth. The World Bank Economic Review, 7, 267-298. https://doi.org/10.1093/wber/7.suppl 1.267

Barro, R. J., \& Sala-i-Martin, X. (2003). Economic Growth (2nd ed.). Cambridge, MA: MIT Press.

Barro, R. J., \& Sala-i-Martin, X. (1995). Economic Growth. Cambridge, MA: MIT Press

Bongini, P., Iwanicz-Drozdowska, M., Smaga, P., \& Witkowski, B. (2017). Financial Development and Economic Growth: The Role of Foreign-Owned Banks in CESEE Countries. Sustainability, 9, 335. https://doi.org/10.3390/su9030335

Bruno, M., \& Easterly, W. (1998). Inflation Crises and Long-Run Growth. Journal of Monetary Economics, 41, 3-26. https://doi.org/10.1016/S0304-3932(97)00063-9

Chaturvedi, V., Kumar, B., \& Dholakia, R. H. (2009). Inter-Relationship between Economic Growth, Savings and Inflation in Asia. Journal of International Economic Studies, 23, 1-22. https://doi.org/10.2139/ssrn.1212096

Deininger, K., \& Okidi, J. (2003). Growth and Poverty Reduction in Uganda. Develop- 
ment Policy Review, 21, 481-509. https://doi.org/10.1111/1467-7679.00220

Dhungana, B. R. (2014). Does Financial Institution Support for Economic Growth? A Case of Nepal. Economic Literature, 12, 56-68. https://doi.org/10.3126/el.v12i0.14888

Didas, T. (2017). Factors Affecting Economic Growth in Uganda (1994-2016). A dissertation submitted to the College of Business and Management Sciences, Kampals: Makerere University. http://dissertations.mak.ac.ug/handle/20.500.12281/5798?show=full

Ding, S., \& Knight, J. (2008). Can the Augmented Solow Model Explain China's Economic Growth? A Cross-Country Panel Data Analysis (Discussion Paper Series No. 380). Oxford: University of Oxford.

Domar, E. (1946). Capital Expansion, Rate of Growth, and Employment. Econometrica, 14, 137-147. https://doi.org/10.2307/1905364

Ellis, A., Manuel, C., \& Blackden, M. (2006). Gender and Economic Growth in Uganda, Unleashing the Power of Women. Washington DC: The International Bank for Reconstruction and Development/Bank. https://doi.org/10.1596/978-0-8213-6384-3

Faria, J. R., \& Carneiro, F. G. (2001). Does High Inflation Affect Growth in the Long and Short-Run? Journal of Applied Economics, 4, 89-105. https://doi.org/10.1080/15140326.2001.12040559

Fadhil, M. A., \& Almsafir, M. K. (2015). The Role of FDI Inflows in Economic Growth in Malaysia (Time Series: 1975-2010). Procedia Economics and Finance, 23, 1558-1566. https://doi.org/10.1016/S2212-5671(15)00498-0

Ford, T. C., Rork, J. C., \& Elmslie, B. T. (2008). Foreign Direct Investment, Economic Growth, and the Human Capital Threshold: Evidence from US States. Review of International Economics, 16, 96-113. https://doi.org/10.1111/j.1467-9396.2007.00726.x

Giovanni, J., \& Shambaugh, J. (2008). The Impact of Foreign Interest Rate on the Economy: The Role of Exchange Regime. Journal of International Economics, 74, 341-361. https://doi.org/10.1016/j.jinteco.2007.09.002

Goldsmith, R. W. (1959). Financial Structure and Development as a Subject for International Comparative Study. In The Comparative Study of Economic Growth and Structure (pp. 114-123). National Bureau of Economic Research.

Grandy, C. (1999). Through a Glass: An Economic View of Fairness, Globalisation and States. In Dator, J., Pratt, D., \& Seo, Y. (Eds.), Fairness, Globalization, and Public Institutions: East Asia and Beyond (pp. 49-60). Honolulu, HI: University of Hawai'i Press. https://doi.org/10.2307/j.ctv3zp081.9

Grossman, G., \& Helpman, E. (1991). Innovation and Growth in the World Economy. Cambridge, MA: MIT Press.

Hansen, L. P. (1982). Large Sample Properties of Generalized Method of Moments Estimators. Econometrica, 50, 1029-1054. https://doi.org/10.2307/1912775

Har, W. M., Teo, K. L., \& Yee, K. M. (2008). FDI and Economic Growth Relationship: An Empirical Study on Malaysia. International Business Research, 1, 11-18.

Harris, M. N., \& Mátyás, M. G. L. (2001). The Negative Inflation-Growth Effect: Theory and Evidence. Melbourne Institute Working Paper No. 12/01, Australia: The University of Melbourne.

Harrison, A., \& Hanson, G. (1999). Who Gains from Trade Reform? Some Remaining Puzzles. Journal of Development Economics, 59, 125-154. https://doi.org/10.1016/S0304-3878(99)00008-5

Harrod, R. F. (1939). An Essay in Dynamic Theory. The Economic Journal, 49, 14-33. https://doi.org/10.2307/2225181 
Hussain, M. E., \& Haque, M. (2016). Foreign Direct Investment, Trade, and Economic Growth: An Empirical Analysis of Bangladesh. Economies, 4, 7. https://doi.org/10.3390/economies4020007

Huchet-Bourdon, M., Le Mouël, C., \& Vijil, M. (2017). The Relationship between Trade Openness and Economic Growth: Some New Insights on the Openness Measurement Issue. The World Economy, 41, 59-76. https://doi.org/10.1111/twec.12586

Islam, N. (1995). Growth Empirics: A Panel Data Approach. The Quarterly Journal of Economics, 110, 1127-1170. https://doi.org/10.2307/2946651

Islam, R. (2010). The Challenge of Jobless Growth in Developing Countries: An Analysis with Cross-Country Data. BIDS Occasional Paper Series No. 1, Dhaka: Bangladesh Institute of Development Studies: Dot Printing and Packaging.

Johansen, S. (1988). Statistical Analysis of Cointegration Vectors. Journal of Economic Dynamics and Control, 12, 231-254. https://doi.org/10.1016/0165-1889(88)90041-3

Jones, C. (1995). R\&D-Based Models of Economic Growth. Journal of Political Economy, 103, 759-784. https://doi.org/10.1086/262002

Kenganzi, J. (2018). Factors Affecting Uganda's Economic Growth: An Autoregressive Distributed Lag Approach. Masters Research Report, Kampala: Makerere University. http://hdl.handle.net/10570/7143

King, R. G., \& Levine, R. (1993). Finance and Growth: Schumpeter Might Be Right. The Quarterly Journal of Economics, 108, 717-737. https://doi.org/10.2307/2118406

Klasen, S., \& Lawson, D. (2007). The Impact of Population Growth on Economic Growth and Poverty Reduction in Uganda. http://hdl.handle.net/10419/31966

Kormendi, R., \& Meguire, P. (1985). Macroeconomic Determinants of Growth: CrossCountry Evidence. Journal of Monetary Economics, 16, 141-163.

https://doi.org/10.1016/0304-3932(85)90027-3

Kripfganz, S., \& Schneider, D. C. (2018). Response Surface Regressions for Critical Value Bounds and Approximate p-values in Equilibrium Correction Models. Manuscript, Exeter: University of Exeter and Max Planck Institute for Demographic Research.

Leliveld, A. (2008). Growth Accelerations in Developing Countries: Uganda and Cambodia Compared. Working Paper for the Tracking Development Project, Leiden, Netherlands: African Studies Centre.

Lenka, S. K. (2015). Does Financial Development Influence Economic Growth in India? Theoretical and Applied Economics, 22, 159-170.

Levine, R., \& Renelt, D. (1992). A Sensitivity Analysis of Cross-Growth Regression. American Economic Review, 82, 942-963.

Lucas Jr., R. E (1988). On the Mechanics of Economic Development. Journal of Monetary Economics, 22, 3-42. https://doi.org/10.1016/0304-3932(88)90168-7

Lucas Jr., R. E. (2000). Some Macroeconomics for the 21st Century. Journal of Economic Perspectives, 14, 159-168. https://doi.org/10.1257/jep.14.1.159

Maddala, G. S. (1977). Econometrics. New York, McGraw-Hill.

Mallik, G., \& Chowdhury, A. (2001). Inflation and Economic Growth: Evidence from four South Asian Countries. Asia-Pacific Development Journal, 8, 123-135.

Mankiw, N., Romer, D., \& Weil, D. (1992). A Contribution to the Empirics of Economic Growth. Quarterly Journal of Economics, 107, 407-437.

https://doi.org/10.2307/2118477

McKinnon, R. I. (1973). Money and Capital in Economic Development. Washington DC: The Brookings Institution Press. 
McQuinn, K., \& Whelan, K. (2007). Solow (1956) as a Model of Cross-Country Growth Dynamics. MPRA Paper No. 5892, Central Bank of Ireland. http://mpra.ub.uni-muenchen.de/5892/

Mutinda, D. M. (2014). The Effect of Lending Interest Rate on Economic Growth in Kenya. Unpublished Research Project for M.Sc., Nairobi, Kenya: University of Nairobi.

Najet, E., \& Sanli, A. (1999). Long-Run Growth Effect of the Physical Capital-Human Capital Complementarity: An Approach by Time Series Techniques. https://www.researchgate.net/publication/229050810 Long-Run Growth Effect of th e Physical Capital-Human Capital Complementarity An Approach by Time Serie $\underline{\text { s Techniques }}$

Nehru, V., \& Dhareshwar, A. (1993). A New Database on Physical Capital Stock: Sources, Methodology and Results. Rivista de Analisis Economico, 8, 37-59.

Nicholas, M. O. (2010). Interest Rate Deregulation, Bank Development and Economics Growth in South Africa: An Empirical Investigation. International Business and Economic Journals, 9, 131-143. https://doi.org/10.19030/iber.v9i11.39

Nkurunziza, J. D., \& Bates, R. H. (2004). Political Institutions and Economic Growth in Africa. Working Paper, No. 98, Center for International Development, Harvard University.

Nurina, S., \& Semuel, H. (2015). Analysis of the Effect of Inflation, Interest Rates, and Exchange Rates on Gross Domestic Product (GDP) in Indonesia. Proceedings of the International Conference on Global Business, Economics, Finance and Social Sciences (GB15_Thai Conference), Bangkok, Thailand, 20-22 February 2015, Paper ID: T507, $1-13$.

Obamuyi, T. M., \& Olorunfemi, S. (2011). Financial Reforms, Interest Rate Behavior and Economic Growth in Nigeria. Journal of Applied Finance \& Banking, 11, 39-55.

Obwona, M. B. (2002). Determinants of FDI and Their Impact on Economic Growth in Uganda. African Development Review, 13, 46-81. https://onlinelibrary.wiley.com/doi/abs/10.1111/1467-8268.00030

Onyango, R. A., \& Were, M. (2015). Determinants of Economic Growth in East African Community. International Journal of Economics, Commerce and Management, 3, 1183-1196.

Osuala, A. E., Osuala, K. I., \& Onyeike, S. C. (2013). Impact of Inflation on Economic Growth in Nigeria-A Causality Test. Journal of Research in National Development, 11, 206-216.

Patrick, H. T. (1966). Financial Development and Economic Growth in Underdeveloped Countries. Economic Development and Cultural Change, 14, 174-189. https://doi.org/10.1086/450153

Pesaran, M. H., Shin, Y., \& Smith, R. J. (2001). Bounds Testing Approaches to the Analysis of Long-Run Relationship. Journal of Applied Econometrics, 16, 289-326 https://doi.org/10.1002/jae.616

Phillips, R. J., \& Cutler, H. (1998), Domestic Exchange Rates and Regional Economic Growth in the United States, 1899-1908: Evidence from Cointegration Analysis. The Journal of Economic History, 58, 1010-1026.

https://doi.org/10.1017/S0022050700021707

Pollin, R., \& Zhu, A. (2006). Inflation and Economic Growth: A Cross-Country Nonlinear Analysis. Journal of Post Keynesian Economics, 28, 593-614.

https://doi.org/10.2753/PKE0160-3477280404

PWC (2017). Price Water Cooper Annual Report, 2017-2018. 
https://www.pwc.nl/nl/assets/documents/pwc-annual-report-2017-2018.pdf

Rahman, M. H. (2004). Financial Development-Economic Growth Nexus: A Case Study of Bangladesh. The Bangladesh Development Studies, 30, 113-127.

Rao, B., B. (2006). Time Series Econometrics of Growth Models: A Guide for Applied Economists. MPRA Working Paper No. 3372, Suva, Figi: University of South Pacific.

Rodriguez, F., \& Rodrik, D. (2000). Trade Policy and Economic Growth: A Skeptic's Guide to the Cross-National Evidence. NBER Working Paper 7081.

Romer, P. (1986). Increasing Returns and Long Run Growth. Journal of Political Economy, 94, 1002-1037. https://doi.org/10.1086/261420

Romer, P. (1990). Endogenous Technological Change. Journal of Political Economy, 98, S71-S102. https://doi.org/10.1086/261725

Sachs, J. D., \& Warner, A. M. (1997). Fundamental Sources of Long-Run Growth. The American Economic Review, 87, 184-188.

Sargan, J. D. (1958). The Estimation of Economic Relationships Using Instrumental Variables. Econometrica, 26, 393-415. https://doi.org/10.2307/1907619

Sattarov, K. (2011). Inflation and Economic Growth. Analyzing the Threshold Level of Inflation: Case Study of Finland, 1980-2010. Master's Thesis, 15 ECTS, Universitet UMEA. http://www.diva-portal.org/smash/get/diva2:484668/FULLTEXT01.pdf

Saymeh, A. A. F., \& Orabi, M. M. A. (2013). The Effect of Interest Rate, Inflation Rate, GDP, on Real Economic Growth Rate in Jordan. Asian Economic and Financial Review, 3, 341-354.

Schumpeter, J. A. (1911). The Theory of Economic Development: An Inquiry into Profits, Capital, Credit, Interest and the Business Cycle. Translated from the German in 2011 by Redvers Opie, New Brunswick, USA and London, UK: Transaction Publishers.

Sieng, A., \& Yussof, E. (2016). Human Capital Accumulation and Economic Growth in Malaysia-Investigating the Long Run Nexus. Journal Ekonomi Malaysia, 48, 155-166. https://doi.org/10.17576/JEM-2014-4801-13

Silajdzic, S., \& Mehic, E. (2017). The Impact of Environmental Taxes on Competitive Performance of Pollution-Intensive Industries among Transition Economies: Evidence from Panel Analysis. In M. Bilgin, H. Danis, E. Demir, \& U. Can (Eds.), Financial Environment and Business Development (pp. 155-169). Cham: Springer. https://doi.org/10.1007/978-3-319-39919-5 13

Sokang, K. (2018). The Impact of Foreign Direct Investment on the Economic Growth in Cambodia: Empirical Evidence. International Journal of Innovation and Economic Development, 4, 31-38. https://doi.org/10.18775/ijied.1849-7551-7020.2015.45.2003

Solow, R. M. (1956). A Contribution to the Theory of Economic Growth. Quarterly Journal of Economics, 70, 65-94. https://doi.org/10.2307/1884513

Stokey, N. L. (1991). Human Capital, Product Quality, and Growth. Quarterly Journal of Economics, 106, 587-616. https://doi.org/10.2307/2937948

Sweidan, O. D. (2004). Does Inflation Harm Economic Growth in Jordan? An Econometric Analysis for the Period 1970-2000. International Journal of Applied Econometrics and Quantitative Studies, 1, 41-66.

Themba, C. G., \& Odhiambao, N. M. (2018). Electricity Consumption and Economic Growth: New Evidence from Twelve Countries. Working Papers 23508, Pretoria: Department of Economics, University of South Africa.

Tridico, P. (2007). Institutions, Human Development and Economic Growth in Transition Economies. The European Journal of Development Research, 19, 569-593. 


\section{https://doi.org/10.1080/09578810701667607}

Wacziarg, R., \& Welch, K. H. (2008). Trade Liberalization and Growth: New Evidence. The World Bank Review, 22, 187-231. https://doi.org/10.1093/wber/lhn007

World Bank (1994). International Statistics. CD-Rom, Washington DC.

World Bank (2005a). Doing Business in 2005. World Bank, Washington DC.

World Bank (2005b). Uganda: From Periphery to Center: A Strategic Country Gender Assessment. Poverty Reduction and Economic Management, Africa Region. World Bank, Washington, DC.

Yanikkaya, H. (2003). Trade Openness and Economic Growth: A Cross Country Empirical Investigation. Journal of Development Economics, 72, 57-89.

https://doi.org/10.1016/S0304-3878(03)00068-3

Zhang, K. H. (2001). How Does Foreign Direct Investment Affect Economic Growth in China? Economics of Transition, 9, 679-693. https://doi.org/10.1111/1468-0351.00095 